\title{
Discussion on Reasons and Countermeasures for Academic Development of Professional Degree Graduate Students
}

\author{
Jiaxuan Guo \\ Beijing Key Laboratory of new technology in \\ agricultural application, College of Plant and \\ Technology \\ Beijing University of Agriculture \\ Beijing 102206, P. R. China \\ guojiaxuangjx@163.com
}

\author{
Chunxia $\mathrm{Wu}$ \\ Beijing Key Laboratory of new technology in \\ agricultural application, College of Plant and \\ Technology \\ Beijing University of Agriculture \\ Beijing 102206, P. R. China \\ Chunxia846@163.com
}

\begin{abstract}
With the constant expansion of graduate enrollment and talent requirements of China's economic development, China launched a "full-time professional Master of Education. Professional degree education has become an important part of China's Academic Degrees and Graduate Education. But in recent years, professional degree graduate presents the trend of academic development. This phenomenon has caused us a great deal of attention and reflection. In this paper, we analyze that reasons and countermeasures for academic development of professional degree graduate students, providing a reference for the sustainable development of professional degree education.
\end{abstract}

Keywords: professional degree; personnel training; academic development

\section{INTRODUCTION}

From 1991, Professional degree program began in China, and has set up 19 kinds of professional degree. Since 2003, China began expanding the enrollment of postgraduate, admission scale has been increasing continuously. Since 2009 , in order to get along with the large scale of graduate students and to meet the demand for skilled talents in China's economic development, the Ministry of Education launched the "full-time professional master-degree" as a model of graduate education for most of professional degree, including crops, horticulture and other agriculture-related professional degree. After three years of pilot and development, agriculture-related professional degree education has become an important part of China's Academic Degrees and Graduate Education in related universities. But in recent years, due to employment pressure and the training model that emphasis academic knowledge, in consideration of their own career development as well as other reasons, postgraduates of professional degree start to favor the trend of "academic development". We should pay attention to this phenomenon. We should provide appropriate guidance and find out countermeasure, so that the professional masterdegree training can develop along the right direction. In this article, we analysis why postgraduates of professional degree start to favor the trend of "academic development", we also explore countermeasure, in order to provide advice for sustainable development of the professional postgraduates education.

\section{THE BACKGROUND OF PROFESSIONAL MASTER- DEGREE ENROLLMENT IN CHINA}

Since 2003, China began expanding the enrollment of postgraduate, admission scale has been increasing continuously, more than doubled in 10 years. Since 2009, in order to get along with the large scale of graduate students and to meet the demand for skilled talents in China's economic development, the Ministry of Education launched the "full-time professional master-degree" as a mainly model of graduate education. On the 14th meeting of the Academic Degrees Committee of the State Council, "Provisional rules on setting and approval of professional degree training programs" was deliberated and approved, article II stipulates: "As a degree with occupation background, the professional master-degree is aimed at training high-level talents for specific occupations". The objective is to "accelerate the training of high-level application-oriented professionals to meet the demand of economic construction and social development". So far, China has established two postgraduate degree systems: academic degree and professional degree; the former is focused on theoretical knowledge and academic research, the latter is focus on specific occupational background and professional skills [1].

After three years of pilot and development, professional degree education has become an important part of China's Academic Degrees and Graduate Education. In 2009, the Ministry of Education approved the pilot enrollment plan for 50,000 candidates of full-time professional master-degree. In 2010 , the government reduced the number of academic postgraduate enrollment by 38,000 , and expanded the number of professional postgraduate enrollment by 38,000 on the basis of previous year (the total number of professional postgraduate enrollment was 88,000 in 2010). In 2011, the government has enrollment plan for 148,000 candidates of full-time professional master-degree. Toward the end of the 12th Five-Year National Plan, the Ministry of Education hopes to balance the enrollment number of academic postgraduates and professional postgraduates according to the ratio of 1:1 [2-3]. 


\section{THE NEW CAREER TREND OF FULL-TIME}

PROFESSIONAL HORTICULTURE GRADUATE STUDENTS IN BEIJING UNIVERSITY OF AGRICULTURE

Beijing University of agriculture is general undergraduate colleges of agriculture and forestry in the city of Beijing, it has formed the system of multi-level talents training for undergraduate and postgraduate agricultural degree. In 2009, Beijing University of Agriculture has the first enrollment of 8 students for full-time professional master-degree in horticulture, two years later, in 2011, the 8 students have graduated, one of them has been admitted to PhD program, the others entered the job market for village officials and company employees. In 2010, Beijing University of Agriculture has the second enrollment of 16 students for fulltime professional master-degree in horticulture, two years later, in 2012, the 16 students have graduated, six of them have been admitted to $\mathrm{PhD}$ program, the admission rate is close to $40 \%$, whereas only one graduate of academic master-degree in horticulture has been admitted to $\mathrm{PhD}$ program. Postgraduates of professional degree start to favor the trend of "academic development".

IV. THE REASON OF WHY POSTGRADUATES OF PROFESSIONAL DEGREE START TO FAVOR THE TREND OF "ACADEMIC DEVELOPMENT"

Full-time professional horticulture graduate students in Beijing University of agriculture has new career trend of "academic development", we are deeply aware of this phenomenon and have reflected upon the underlying causes. We analysis the main reasons for professional postgraduates to favor "academic development" as follows:

\section{A. The Training Model That Emphasis Academic \\ Knowledge}

The professional degree graduate training program basically copied the training model of academic postgraduate, with no distinctive features in the training model for professional degree graduates. The curriculum system for professional master-degree is basically consistent with those for academic master-degree, education is focused on the learning of theoretical knowledge, without stressing that professional degree should aim for technical, practical, hands-on skills, the consequence is that admission into $\mathrm{PhD}$ program become a more tempting and realistic opportunity for professional degree graduate.

Professional degree students are mainly forthcoming or previous college graduates, not social workers with practical work experience. These professional degree students mainly studied a system theoretical knowledge, but lack of practical work experience and the demand for improving work capacity levels.

At present, most universities didn't set up full-time teachers for professional master's students, and usually by research or research -based teaching part-time teachers. Those teachers mainly have high levels in theoretical research region, and weak social production practices and technique. In order to realize the goal of training "application-type" talents in professional degree training, the education of full-time teachers must be strengthened.

\section{B. Caused by the Employment Pressure}

The professional degree graduate training focus on specific occupational background and professional skills, therefore should have advantage in the job markets for skilled professionals, with better employment opportunities, however, because of the short training time and the society lack understanding of this new training program, therefore the professional degree graduates face a lot of pressure in the job markets, their employment rate and quality is generally worse than those of the three-year academic master-degree graduates. Competing for admission into $\mathrm{PhD}$ program has undoubtedly become the obvious solution to avoid the employment pressure.

\section{Profession Master-Degree Graduate Students Desire to Pursue Further Studies}

In the course of postgraduate training, with the accumulation of academic knowledge and the interest aroused by academic reports, the professional master-degree graduate students become interested in academic research, and inevitably desire to pursue further studies.

In addition, because they lack clear understanding of this new training program, the professional master-degree graduate students may feel inferior to the three-year academic master-degree graduates, and therefore are motivated to aim for $\mathrm{PhD}$ admission.

\section{The Equivalence of "Continuous Academic Program \\ That Involves Postgraduate and Doctoral Study" is Very Tempting}

The current domestic "continuous academic program that involves postgraduate and doctoral study" requires five years. Therefore, compared with three-year academic masterdegree graduates, the two-year professional degree graduate students who gain direct admission to $\mathrm{PhD}$ program can save one year to get a doctoral degree, which is tempting opportunity for them.

\section{COUNTERMEASURES FOR THE TREND OF "ACADEMIC DEVELOPMENT" AMONG PROFESSIONAL DEGREE GRADUATES}

Postgraduates of professional degree start to favor the trend of "academic development", this new phenomenon apparently contradicts with the original purpose in launching the national professional master-degree, although we are not able to simply change the trend by force, we have to provide appropriate guidance and find out countermeasure, so that the professional master-degree training can develop along the right direction:

\section{A. Expanding the Professional Master-Degree Training Base}

In order to ensure the quality of postgraduates education, the top priority should be strengthening the construction of professional master-degree training base, we should be fully aware that construction of the practical platform for "skill development' is the most important and challenging task in 
the sustainable development of full-time professional masterdegree education. This can be achieved through strengthening the cooperation between universities and farms, business, industry, or other university etc. Through establishing various workable cooperation mechanisms, professional degree students can know more skills and practical analysis over theory and research.

Beijing University of Agriculture is the exclusive ordinary institution of higher education in the city of Beijing which specializes in granting bachelors' degrees in different branches of learning in the realms of farming and forestry studies. Construction of practice teaching system, training peri-urban modernistic agriculture characteristic talents and services Capital 'Agriculture ' are the main objectives and mission of Beijing University of Agriculture. University cooperate with large agribusiness, research institutes, universities and other units fraternal, and have set up 154 Practice base outside school, such as new rural construction research base, etc. Some senior technical staffs are hired as a student practice teaching part-time instructor for training complex agricultural talents.

\section{B. Strengthening the off-Campus Mentor Team and Full- Time Techers for Teaching Practical Skill to Professional Degree Postgraduate}

In order to ensure the quality of postgraduate education, it is important to strengthen the off-campus mentor team and full-time teachers for teaching practical skill to professional degree postgraduate. We should expand our selection of offcampus mentor teams, from relative group of companies and production frontier. Although off-campus mentors may not have strong academic achievement and not good at theoretical instruction, they have practical skill in analyzing and solving problems. Therefore, off-campus mentors and university professors can learn from each other and complement each other, in order to provide better training as well as practical guidance for professional master-degree graduates, and to improve the quality of graduate education for professional master-degree program. Meanwhile degree education set up mentoring, and set up a separate full-time faculty positions. In principle, full-time faculty don't allow part-time teacher of other courses, and partly full-time teachers must be workers with specific professional experience.

\section{Attention to the Educational System and Evaluation}

In order to ensure the quality of postgraduate education, it is important to improve the educational system for teaching practical skill to professional degree postgraduate. Professional degree education is to train high-level professional careers in human practice of education, rather than for the purpose of training researchers. So, carrying out systematic instruction centered practice and technique education for students will be more effective, compared with a particular research topic to study and then summarize the results of the educational methods made for the students. Then, educational methods for students are not on individual research guidance, but should be underlined the need for close contact with the practical teaching, and pay attention to flexible teaching methods such as case studies, field surveys, multi-party discussions, multimedia teaching, distance learning and others.

In order to actively promote the improvement of education, and train high-level specialized personnel, professional degree education system should establish and strengthen a rigorous and detailed assessment of third-party certification system, focuses on faculty, curriculum, student assessment support system, etc.

\section{Implementing Preferential Employment Policies and Channels for Professional Master-Degree Students}

With the expansion of graduate education for professional master-degree students, it is also important to expand employment channels for them. On the one hand, we should improve the educational quality for professional master-degree graduates and develop their capabilities to provide professional service, so that they can better adapt to society's need for qualified personnel. On the other hand, the state should effectively coordinate the relevant departments, to implement preferential employment policies and channels for professional master-degree students, in order to improve the rate and quality of their employment, and thus effectively promote the healthy development of the professional masterdegree education. For example, a certain percentage of village officials should be recruited directly from among fresh graduates with professional degree. So that their knowledge and techniques can be played in related fields, and promote the development of agriculture and rural farmers.

\section{SUMMARY}

The professional master-degree training is a complicated systematic project, which depends on the support of government, universities, enterprises, society [4-6]. Coordination among relevant departments are important as a starting point to improve the thesis quality for professional master-degree graduates, the subjects of their thesis should originate from enterprises and business production, the results of thesis research can be directly applied to production, and able to solve practical problems. In professional master-degree graduate education, the practical platform for "skill development' is not only a place for training and learning, but also a channel for future employment. We should regard promoting employment as the breakthrough point of professional degree graduate training, and focus on ensuring quality employment for professional master-degree graduates, which is the fundamental guarantee for the healthy development of professional degree graduate education.

\section{ACKNOWLEDGMENT}

This work was supported by National Key Technology Supported Program of China ((Project 2011BAD32B03).

\section{REFERENCES}

[1] X. Y. Zhuang, "Study on Professional degree postgraduate education and quality assurance", Journal of Changchun university of science 
and technology (social sciences edition), 2011, Vol.24, No.11, pp.129-130.

[2] D. E. Pan, D. M. Pan and Q. Q. Lin, "Exploration of development of the internationalization of professional master education in China", Higher agricultural education, 2009, No.4, pp.62-67.

[3] A. R. Liu, S. C. Chen and G. Q. Chen, "Exploration and practice in training pattern of academic degree postgraduates in horticultural science", Higher education forum, 2012, No.12, pp.118-119.
[4] Y. Tao, X. R. Zhang, J. P. Ding and Y. G. Wang, "Analysis of problems and reasons in agricultural professional master degree thesis writing", China higher education research, 2005, No.10, pp.30-33.

[5] H. Chen and T. Q. Hu, "Professional degree education: problems and solutions", Journal of Zhejiang normal university (social science), 2010, Vol.35, No.2, pp.88-92.

[6] P. Hurst, P. Termine, and M. Karl, "Agricultural workers and their contribution to sustainable agriculture and rural development", FAOILO-IUF, Geneva: ILO, 2007 